\title{
PENGARUH PENAMBAHAN PAKAN BERBAHAN DASAR MAGGOT DAN DEDAK PADI PADA PAKAN BASAL TERHADAP BOBOT HIDUP, KARKAS DAN GIBLET AYAM BROILER
}

\section{(Effect of Addition of Maggot and Rice Bran-Based Feed-In Basal FeedAgainst Live Weight of Broiler Carcass and Giblet)}

\author{
Kastalani $^{1}$, Maria Erviana Kusuma ${ }^{2}$ Herlinae $^{2}$ dan Yemima ${ }^{2}$ \\ ${ }^{1}$ Program Studi Agribisnis Fakultas Agribisnis Universitas Nahdlatul Ulama Kalimantan Selatan \\ ${ }^{2}$ Program Studi Peternakan Fakultas Peternakan Universitas Kristen Palangka Raya \\ Penulis koresponden: kastalani460 ymail.com
}

Article Submitted: $11-12-2020$

Article Accepted: 25-12-2020

\begin{abstract}
The purpose of this study was to determine the effect of adding feed with maggot and rice bran as a base ingredient in basal feed on live weight, carcass, and giblets of broiler chickens and to determine the rate of addition of feed with maggot and rice bran as a base ingredient in basal feed which will give good results. best on live weight, carcass, and broiler chicken giblets. The implementation of this research took place at the practical location of the Faculty of Animal Husbandry, Palangka Raya Christian University, Jalan G.S Rubay Palangka Raya. This study used a completely randomized design (CRD) with 4 treatments with 5 replications, namely $\mathrm{A}=$ $100 \%$ basal feed, $\mathrm{B}=100 \%$ basal feed and $5 \%$ additional feed, $\mathrm{C}=100 \%$ basal feed and $10 \%$ additional feed and $\mathrm{D}=$ feed. basal $100 \%$ and additional feed $15 \%$. From the results of the study, it can be seen that the addition of feed with maggot and rice bran as a base ingredient in basal feed does not affect live weight, carcass, and broiler chicken giblets.
\end{abstract}

Keywords: maggot, basal feed, carcass, giblets, broiler chickens

\section{PENDAHULUAN}

Kebutuhan manusia terhadap pangan akan semakin meningkat dan juga bertambah selaras dengan pertambahan jumlah penduduk. Untuk itu perlu diupayakan bagaimana meningkatkan sumber pangan tersebut agar dapat lebih maksimal untuk memenuhi kebutuhan pasar. Dalam rangka pemenuhan kebutuhan akan berbagai bahan pangan pemerintah selalu memperhatikan mulai dari pendistribusian ternak, pengawasan berbagai kebutuhan pokok, sehingga menjamin tersedianya berbagai bahan pangan di pasaran secara kuantitas, kualitas dan kontinuitasnya.
Untuk memenuhi kebutuhan pangan hewani secara cepat maka peternakan ayam broiler yang mampu, karena cepatnya pertumbuhan dari ternak tersebut menghasilkan daging. Hal ini karena dagingnya terasa empuk, mudah dimasak dan harganya relatif terjangkau. Namun demikian harganya sering mengalami turun naik sehingga dapat menyebabkan peternak mengalami kerugian

Peternakan merupakan salah satu bagian dari pembangunan nasional dimana mempunyai tujuan tersedianya bahan pangan asal hewan berupa daging, susu serta telur yang mempunyai nilai gizi tinggi, peningkatan pendapatan peternak, bertambah dan meningkatnya devisa dan 
juga memberikan kesempatan dan peluang kerja untuk masa yang akan datang, sehingga pada akhirnya akan meningkatkan pembangunan juga akan meningkatkan perekonomian bangsa (Saragih, 2000).

Rasyaf (2006) menyatakan bahwa ayam broiler adalah tipe ayam pedaging yang didesain dan dikembangkan dengan tujuan khusus untuk dipasarkan pada umur atau usia yang relatif muda, sesuai dengan tujuannya yaitu pertumbuhannya yang cepat, dari segi fisik mempunyai dada yang lebar dan timbunan daging yang banyak. Ciri dari ayam broiler adalah tekstur kulit dan daging yang lembut. Beberapa Faktor yang berpengaruh terhadap kondisi ayam broiler yang baik adalah bibit, pakan dan pemeliharaan (Ensminger, 1992).

Keberhasilan usaha peternakan ayam broiler sangat dipengaruhi oleh faktor pakan, bibit, dan obat-obatan serta pemasaran yang tepat. Faktor pakan dapat diupayakan bagaimana memanfaatkan bahan-bahan pakan yang dapat disubtitusikan pada pakan yang sudah dijual di pasar. Bahan tersebut tersebut tersedia sepanjang tahun, mudah didapat dan memiliki nilai biologis yang baik untuk menunjang pertumbuhan dan produksi ayam broiler. Ternak ayam broiler bisa dikatakan sebagai ternak yang paling ekonomis bila dibandinagkan dengan ternak yang lainnya, salah satu faktor yang menjadi kelebihan dari ayam broiler adalah adalah cepatnya pertumbuhan atau waktu yang diperlukan untuk memproduksi daging relatif cepat dan singkat dimana hanya membutuhkan waktu 4-5 minggu daging sudah dapat konsumsi atau dipasarkan (Murtidjo, 2009).

Maggot dalam istilah bahasa Inggris disebut juga dengan larva. Salah satu ciri dari dari maggot ini adalah hidup dari bungkil kelapa sawit, sehingga maggot berbeda dengan belatung yang biasanya hidup dari daging busuk. Karena hidup dari bungkil kelapa sawit maka dalam hal pengembangannya maggot banyak dilakukan dan dicoba di daerah atau sekitar sentra perkebunan kelapa sawit. "Black Soldier" (Hermetia illucens) merupakan lalat bunga yang membantu perkembangbiakkan maggot. Adapun ciri dari lalat ini adalah mempunyai warna hitam dan berbeda dengan jenis lalat lainnya yang di kenal jorok. Lalat ini adalah merupakan jenis lalat bunga dimana salah satu sifatnya adalah suka bergerombol dalam mengkonsumsi bungkil kelapa dan menghisap madu bunga (Subamia, 2010).

Dedak padi adalah hasil sampingan dan sisa dari proses ketika padi digiling menjadi beras. Di Kalimantan Tengah hingga saat ini masih cukup tersedia walaupun harganya relatif lebih mahal dari daerah lainnya. Hal ini disebabkan karena dedak padi banyak dimanfaatkan untuk ternak peliharaan seperti pada ternak ayam dan babi. Namun pemrosesan hingga sampai dibuat fermentasinya masih sangat kurang bahkan bisa dikatakan belum ada di kalangan peternak (Anggorodi, 1994).

Dedak padi yang telah difermentasi nilai nutrisinya akan meningkat dan lebih baik. Pada saat proses fermentasi, mikroorganisme yang ditambahkan mengubah komponen yang lebih kompek menjadi senyawa yang lebih sederhana sehingga lebih mudah dicerna. Fermentasi akan menyebabkan berubah atau dirombaknya struktur jaringan dinding sel, terputusnya ikatan lignoselilosa dan turunnya kadar lignin (Mahardika, 2015).

Berdasarkan berbagai uraian diatas maka dirasakan perlu dilaksanakan penelitian dengan judul "Pengaruh Penambahan Pakan Berbahan Dasar Maggot dan Dedak Padi Pada Pakan Basal Terhadap Bobot dan Persentase Giblet Ayam Broiler".

\section{METODOLOGI PENELITIAN}

Penelitian ini bertempat di Lahan Praktek Fakultas Peternakan Universitas Kristen Palangka Raya Jalan G.S Rubay, RTA Milono Km 8,5 Palangka Raya. Bahan yang digunakan pada penelitian ini adalah pakan basal, pakan tambahan yang terdiri 
dari campuran maggot dan dedak padi, ayam broiler, metode penelitian yang digunakan adalah Rancangan Acak Lengkap (RAL) dengan 5 perlakuan dan 4 ulangan dimana Perlakuan $\mathrm{A}=$ Pakan Basal $100 \%, \mathrm{~B}=$ Pakan Basal + Pakan Tambahan 5\%, C= Pakan Basal 100\% + Pakan Tambahan 10\% dan perlakuan $\mathrm{D}=$ Pakan Basal $\%+$ Pakan Tambahan 15\%. Untuk mengetahui pengaruh dari perlakuan data yang didapat akan dilakukan uji statistik dengan menggunakan analisa sidik ragam (Anova). Bila hasil perhitungan menunjukkan berbeda nyata atau sangat nyata maka akan dilakukan uji lanjutan dengan menggunakan
Uji Duncan Multiple Range Test (Uji DMRT).

\section{HASIL DAN PEMBAHASAN}

\section{Bobot Hidup}

Analisis Sidik Ragam menunjukkan bahwa berbagai perlakuan penambahan pakan dengan bahan dasar maggot dan dedak padi pada pakan basal tidak berpengaruh nyata $\quad(\mathrm{P}>0,05)$ terhadap bobot hidup ayam broiler.

Rataan bobot giblet ayam broiler yang diberikan perlakuan penambahan pakan dengan bahan dasar maggot dan dedak padi pada pakan basal ditampilkan pada Tabel 1 .

Tabel 1. Rataan Bobot Hidup Ayam Broiler.

\begin{tabular}{lc}
\hline \multicolumn{1}{c}{ Perlakuan } & Bobot Hidup (gram/ekor) \\
\hline A (pakan basal 100\%) & 2235,63 \\
B (pakan basal 100\% dan pakan tambahan 5\%) & 2240,27 \\
C (pakan basal 100\% dan pakan tambahan 10\%) & 2273,41 \\
D (pakan basal 100\% dan pakan tambahan 15\%) & 2196,28 \\
\hline
\end{tabular}

Dari Tabel 1 tersebut dapat dilihat bahwa rata-rata bobot hidup pada perlakuan A (pakan basal $100 \%$ ) dengan berat 2235,63 gram, perlakuan B (pakan basal 100 $\%$ dan pakan tambahan $5 \%$ ) diperoleh bobot hidup sebesar 2240,27 gram, perlakuan C (pakan basal $100 \%$ dan pakan tambahan $10 \%$ ) diperoleh bobot hidup sebesar 2273,41 gram dan perlakuan D (pakan basal $100 \%$ dan pakan tambahan 15\%) diperoleh bobot hidup sebesar 2196,28 gram.

Jika dilihat dari tabel 1 tersebut, walau pun secara statistik tidak ada perbedaan yang nyata antar perlakuan, tetapi ada kecenderungan semakin tinggi persentase pakan tambahan berbahan dasar maggot dan dedak padi yang diberikan akan semakin meningkatkan bobot hidup dari ayam broiler, tetapi sampai pada batas tertentu malah cenderung turun, hal ini diduga karena faktor pembatas pada pakan campuran yang mengandung maggot. Maggot adalah hewan yang termasuk ke dalam jenis insekta atau serangga. Insekta mempunyai kandungan nutrisi yang tinggi, baik untuk makronutrisi (protein dan energi) ataupun mikronutrisinya (vitamin dan mineral). Hidayat (2018) menyatakan bahwa variasi kecernaan protein kasar yang tinggi pada maggot diduga disebabkan karena dua hal, pertama adanya komponen nitrogen non protein yang terdiri dari asam nukleat, produk eksresi, kitin dan fospolipid, yang pada saat dilakukan analisis laboratorium akan terukur sebagai protein kasar, tetapi tidak dapat dimanfaatkan oleh tubuh ayam pedaging, kemudian yang kedua karena adanya kitin yang mampu membentuk ikatan kompleks dengan protein menyebabkan protein tidak mampu dicerna dalam saluran pencernaan ayam pedaging. Henry et al. (2015), menyatakan bahwa kitin adalah senyawa polisakarida yang ada pada bagian eksoskeleton arthropoda. Sánchez-Muros et al. (2013). tidak adanya enzim kitinase pada ternak unggas yang juga merupakan ternak 
monogastrik menyebabkan pakan yang diberikan tambahan maggot dan dedak padi yang tidak dapat dicerna.

Semestinya protein yang tinggi dapat memberikan bobot hidup yang tinggi pada perlakuan penambahan maggot dan dedak padi. Wahyu (2004) yang menyatakan bahwa protein memiliki fungsi yang sangat vital bagi ungags, seperti memperbaiki jaringan yang rusak, pertumbuhan jaringan yang baru, pertumbuhan bulu serta pensuplai asam amino.

\section{Bobot Karkas}

Analisis Sidik Ragam menunjukkan bahwa berbagai perlakuan penambahan pakan dengan bahan dasar maggot dan dedak padi pada pakan basal tidak berpengaruh nyata $\quad(\mathrm{P}>0,05)$ terhadap bobot karkas ayam broiler.

Rataan bobot giblet ayam broiler yang diberikan perlakuan penambahan pakan dengan bahan dasar maggot dan dedak padi pada pakan basal ditampilkan pada Tabel.2

Tabel 2. Rataan Bobot Karkas Ayam Broiler.

\begin{tabular}{lc}
\hline \multicolumn{1}{c}{ Perlakuan } & Bobot \\
\hline A (pakan basal 100 \%) & 1543,43 \\
B (pakan basal 100 \% dan pakan tambahan 5\%) \\
C (pakan basal 100\% dan pakan tambahan 10\%) & 1602,70 \\
D (pakan basal 100\% dan pakan tambahan 15\%) & 1659,18 \\
\hline
\end{tabular}

Dari Tabel 2 tersebut dapat dilihat bahwa rata-rata bobot karkas pada perlakuan A (pakan basal $100 \%$ ) dengan berat 1543,43 gram, perlakuan B (pakan basal 100 $\%$ dan pakan tambahan $5 \%$ ) diperoleh bobot karkas sebesar 1602,70 gram, perlakuan C (pakan basal $100 \%$ dan pakan tambahan 10\%) diperoleh bobot karkas sebesar 1659,18 gram dan perlakuan D (pakan basal $100 \%$ dan pakan tambahan 15\%) diperoleh bobot karkas sebesar 1573,28 gram.

Rata-rata bobot karkas pada tabel diatas secara statistik tidak berbeda antar perlakuan dan berada pada kisaran antara 1543,43 gr - 1659,18 gr/ekor. Rataan bobot karkas ini memperlihatkan bahwa bobot karkas yang dihasilkan sudah cukup baik. Hal ini didukung dengan pendapat Fijana et al (2012), yang menyatakan bahwa bobot karkas tinggi menunjukkan kualitas karkas yang baik. Kualitas karkas sendiri dipengaruhi oleh faktor sebelum dan sesudah pemotongan seperti faktor genetik, spesies, bangsa, jenis ternak, jenis kelamin, umur dan pakan. Sedangkan menurut Soeparno (1994) agar mendapatkan kualitas karkas yang baik dan bagus, maka cara dalam pemotongan ayam harus menjadi perhatian.

Daging yang terdiri dari jaringanjaringan yang bertambah oleh adanya asupan zat makanan terutama protein yang masuk sehingga pada akhirnya terbentuk daging, tulang dan kulit yang merupakan bagian dari karkas. Sesuai dengan pendapat Ahmad dan Herman (1982), bahwa protein merupakan usur pokok yang diperlukan untuk penyusun tubuh dan jaringan, dimana untuk pertumbuhan jaringan, perbaikan jaringan dan pengelolaan produksi serta bagian dari struktur enzim, diperlukan kandungan protein dalam ransum yang mencukupi.

Soeparno (1998) menyatakan bahwa protein adalah merupakan zat salah satu zat makanan yang berpengaruh terhadap pertumbuhan jaringan dan juga pembentukan karkas. Pencapaian bobot badan ternak dipengaruhi oleh tingkat protein ransum yang diberikan. Setiadi et al (2011) menyatakan bahwa untuk pembentukan karkas diperlukan protein ynag mencukupi, sesuai dengan kebutuhan yang diperlukan oleh ternak.

Rataan bobot karkas pada tabel 2 tersebut memperlihatkan bahwa berbagai 
tingkat penambahan pakan campuran dengan bahan dasar maggot dan dedak padi pada pakan basal tidak berpengaruh terhadap bobot karkas, walaupun kalau dilihat dari segi kandungan nutrisi yang diberikan berkisar antara 20- 26,15\%. Kisaran ini sudah cukup jauh berbeda, dimana seharusnya semakin banyak penambahan pakan campuran akan semakin tinggi asupan protein, dan akan semakin meningkatkan bobot karkas. Hal ini diduga disebabkan karena adanya faktor pembatas pada maggot yang merupakan jenis insekta dimana di dalam tubuhnya terdapat kitin yang membentuk ikatan kompleks dengan protein yang menyebabkan protein tidak mampu dicerna didalam saluran pencernaan ayam broiler. Tidak berpengaruhnya perlakuan penambahan pakan campuran maggot dan dedak padi terhadap bobot karkas diduga terjadi karena kandungan kitin yang terdapat pada maggot. Henry et al. (2015), menyatakan bahwa kitin adalah senyawa polisakarida yang ada pada bagian eksoskeleton arthropoda. Sánchez-Muros et al. (2013). tidak adanya enzim kitinase pada ternak unggas yang juga merupakan ternak monogastrik menyebabkan pakan yang diberikan tambahan maggot dan dedak padi yang tidak dapat dicerna.

Leeson dan Summers (1980) myatakan bahwa karkas ayam broiler umur 6 minggu berkisar antara 1128,4 - 1523,2 gr/ekor. Adapun Haroen (2003) menyatakan bahwa bobot hidup dan pertambahan bobot badan berkaitan erat dengan bobot karkas yang dihasilkan. Diperlukan perhatian dan manajemen yang khusus tentang penggunaan protein dalam bahan pakan, sehingga kebutuhan broiler akan asam amino yang dibutuhkan bisa terpenuhi, Ketersediaan asam amino sebagai pembentuk jaringan akan berpengaruh terhadap pertambahan bobot badan, karena konsumsi protein pakan berhubungan langsung dengan proses pertumbuhan (Winedar, et al. 2006)

$$
\text { Blakely dan Blade }
$$

menyatakan bahwa tingkat konsumsi ransum akan mempengaruhi laju pertumbuhan dan bobot hidup karena pembentukan bobot, bentuk, dan komposisi tubuh pada hakekatnya adalah akumulasi dari pakanyang dikonsumsi ke dalam tubuh ternak.

Bobot karkas juga menunjukkan bahwa karkas menempati $2 / 3$ bagian dari bobot hidup atau dengan kata lain bahwa $1 / 3$ bagian adalah bulu, kaki, ceker, leher, kepala dan jeroan. Hal ini sesuai dengan pendapat Resnawati (2004) bahwa selama proses pengolahan yaitu dari bentuk ayam yang hidup hingga terwujud daging ayam yang siap untuk dimasak akan terjadi kehilangan berat hidup kurang lebih 1/3 bagian (berat daging siap masak itu nantinya kurang lebih $2 / 3$ dari berat hidupnya), karena berat bulu, kaki, ceker, leher, kepala, jeroan atau isi dalam dan ekor dipisah dari bagian daging tubuh dengan demikian daging hanya tinggal sekitar $75 \%$ saja dari bobot hidup

\section{Bobot Giblet}

Analisis Sidik Ragam menunjukkan bahwa berbagai perlakuan penambahan pakan dengan bahan dasar maggot dan dedak padi pada pakan basal tidak berpengaruh nyata $\quad(\mathrm{P}>0,05)$ terhadap bobot giblet ayam broiler.

Rataan bobot giblet ayam broiler yang diberikan perlakuan penambahan pakan dengan bahan dasar maggot dan dedak padi pada pakan basal ditampilkan pada Tabel.3 
Tabel 3. Rataan Bobot Giblet Ayam Broiler.

\begin{tabular}{lc}
\hline Perlakuan & Bobot Giblet (gram / ekor) \\
\hline A (pakan basal 100 \%) & 78,32 \\
B (pakan basal 100 \% dan pakan tambahan 5\%) & 84,83 \\
C (pakan basal 100 \% dan pakan tambahan 10\%) & 79,47 \\
D (pakan basal 100 \% dan pakan tambahan 15\%) & 80,95 \\
\hline
\end{tabular}

Dari Tabel 3 tersebut dapat dilihat bahwa rata-rata bobot giblet pada perlakuan A (pakan basal $100 \%$ ) dengan berat 78,32 gram, perlakuan B (pakan basal $100 \%$ dan pakan tambahan $5 \%$ ) diperoleh bobot giblet sebesar 84,83 gram, perlakuan C (pakan basal $100 \%$ dan pakan tambahan 10\%) diperoleh bobot giblet sebesar 79,47 gram dan perlakuan D (pakan basal $100 \%$ dan pakan tambahan 15\%) diperoleh bobot giblet sebesar 80,95 gram.

Tidak berbedanya bobot giblet ini, hal ini diduga karena jumlah ransum yang dikonsumsi selama ini juga tidak berbeda. Sejalan dengan apa yang dikemukakan oleh Soeparno (1998), dimana salah satu faktor yang dapat mempengaruhi bobot giblet adalah konsumsi ransum, apabila konsumsi ransum tinggi, maka bobot giblet juga akan tinggi. Karena semakin tinggi konsumsi ransum maka akan semakin banyak kandungan nutrisi yang masuk kedalam tubuh ternak. Bobot giblet juga dipengaruhi oleh kandungan nutrisi ransum yang diberikan kepada ternak, terutama kandungan serat kasarnya.

Selain itu kandungan serat kasar pada pada masing-masing perlakuan yang digunakan pada penelitian ini tidak jauh berbeda, berkisar antara $4-5,13 \%$ dan masih dalam batas toleransi. Wahju (1997) menyatakan bahwa batas toleransi kandungan serat dalam ransum yang perbolehkan untuk ungggas tidak boleh melebihi $6 \%$. Kandungan serat kasar yang tinggi dalam ransum akan menyebabkan aktivitas metabolisme yang tinggi pada tubuh ternak, dan akan memicu giblet untuk mendukung metabolism tersebut. Walaupun konsumsi serat kasar pada tiap perlakuan berbeda namun hal tersebut tidak menyebabkan bobot giblet yang berbeda.

Hetland et al., (2005) dalam Jumiati et al., (2017) menyatakan bahwa ketika ransum dikonsumsi dan masuk ke dalam tubuh tubuh ternak maka akan terjadi proses metabolisme. Aktivitas kerja dari gizzard, hati, dan jantung dipengaruhi oleh prose metabolism ini. Untuk mencerna serat kasar yang masuk maka unggas akan meningkatkan kemampuan, semakin tinggi aktivitas metabolisme maka akan semakin meningkatkan ukuran gizzard, hati, dan jantung. Hal ini juga sesuai dengan pendapat Akoso (1998), yang menyatakan bahwa besar dan ukuran gizzard dari ternak sangat tergantung pada aktivitasnya,. Aktivitas otot pada gizzard akan terjadi apabila ada ransum yang dikonsumsi oleh ternak.

Tidak berpengaruhnya bobot giblet pada penelitian ini diduga karena bobot hidup yang tidak berpengaruh pula, dimana bobot giblet akan sejalan dengan bobot hidup. Kurtini et al., (2014), menyatakan bahwa giblet adalah hasil ikutandari ternak unggas, yang terdiri dari jantung, hati, serta gizzard (rempela). Sementara Ressang (1993) menyatakan bahwa bangsa, umur, bobot tubuh, obat-obatan serta ransum merupakan beberapa faktor yang memengaruhi bobot giblet.

Tidak berpengaruhnya perlakuan penambahan pakan campuran maggot dan dedak padi terhadap bobot giblet diduga terjadi karena kandungan kitin yang terdapat pada maggot. Henry et al. (2015), menyatakan bahwa kitin adalah senyawa polisakarida yang ada pada bagian eksoskeleton arthropoda. Sánchez-Muros et al. (2013). tidak adanya enzim kitinase pada 
ternak unggas yang juga merupakan ternak monogastrik menyebabkan pakan yang diberikan tambahan maggot dan dedak padi yang tidak dapat dicerna.

Ternak ayam dilaporkan memiliki enzim kitinase dalam saluran pencernaannya, akan tetapi kemampuannya sangat terbatas untuk memanfaatkan kitin (Sanchez-Muros et al. 2014). Kitin akan membentuk senyawa ikatan kompleks dengan protein sehingga pada akhirnya protein tidak bisa dicerna dalam saluran pencernaan ayam pedaging. Lebih lanjut dikemukakan oleh Ijaiya dan Eko (2009) bahwa pembatas penggunaan insekta dalam ransum ayam pedaging adalah keberadaan kitin. Kitin sebagian besar tidak bisa dicerna dalam saluran pencernaan ayam pedaging dan mengakibatkan tidak tercernanya zat gizi lain, terutama protein, karena kitin mempunyai kemampuan membentuk ikatan kompleks dengan zat gizi lain, terutama protein, sehingga menjadikan protein tidak dapat dicerna dalam saluran pencernaan. Hal inilah yang diduga turut menyebabkan bobot giblet tidak berbeda.

Akoso (1993), menyatakan bahwa aktifitas akan berbengaruh terhadap besar kecilnya gizzard, sehingga apabila ayam terbiasa diberikan pakan yang sudah digiling maka akan menyebabkan gizzard menjadi lisut atau mengkerut. Hal ini sejalan dengan apa yang dikemukakan oleh siregar Siregar (2011) yang menyatakan bahwa bobot badan, jumlah, sifat, serat kasar yang terkandung dalam pakan, dan juga kekasaran dari tekstur akan sangat menentukan bobot dari rempela. Dalam penelitian ini pakan yang digunakan bila dilihat dari segi teksturnya , serat kasar serta banyaknya atau jumlah yang dikonsumsi oleh ternak cenderung sama, sehingga pada akhirnya menyebabkan kerja dari gizzard atau rempela cenderung sama pula sehingga bobot dari gizzard akan cenderung sama pula. Pakan yang mempunyai tekstur yang keras akan menyebabkan aktivitas berlebih pada gizzard, sehingga membuat otot lebih aktif dan menebal, Gizzard yang lebih berat bobotnya menandakan bahwa gizzard tersebut bekerja lebih berat dalam mencerna makanan yang diberikan. Hal ini sesuai dengan pendapat Akoso (2010) bobot gizzard yang lebih berat menandakan bahwa gizzard bekerja lebih berat dan keras dalam mencerna makanan, ketika diberikan pakan dengan tekstur yang keras dan serat kasar yang lebih tinggi.

\section{KESIMPULAN}

Dari hasil penelitian ini dapat diambil kesimpulan penambahan pakan berbahan dasar dasar maggot dan dedak padi pada pakan basal tidak berpengaruh terhadap bobot hidup, karkas dan juga giblet ayam broiler.

\section{DAFTAR PUSTAKA}

Ahmad, B.H dan R. Herman. 1982. Perbandingan Produksi Daging Antara Ayam Jantan, Kampung dan Ayam Jantan Petelur. Media Peternakan. Jakarta. 11-15

Akoso, B. T. 1998. Manual Kesehatan Unggas. Panduan Bagi Petugas Teknis, Penyuluh dan Peternak. Kanisius, Yogyakarta

Anggorodi, $\quad$ R. $1994 . \quad$ Ilmu MakananTernakUnggas.

KemajuanMutakhir. Universitas Indonesia, Jakarta.

Blakely, D dan D.H. Bade. 1991. Ilmu Peternakan. Edisi ke-4. Gadjah Mada University Press. Yogyakarta.

Ensminger. 1992. Poultry Science. Interstate Publishers, Inc., Illinois. 3441

Fijana, M.F., Suprijatna. E dan Atmomarsono, U. 2012. Pengaruh Proprsi Pemberian Pakan Pada Siang, Malam Hari, Pencahayaan Pada Malam Hari Terhadap Produksi 
Karkas Ayam Broiler. Animal Agricultural Juornal 1 (1) 697-710

Haroen, U. 2003. Respon Ayam Broiler Yang Diberi Tepung Daun Sengon (Abizzia falcataria) Dalam Ransum Terhadap Pertumbuhan dan Hasil Karkas. Jurnal Ilmiah Ilmu-ilmu Peternakan 6 (1)

Hetland. 2005. Role of Insoluble Fiber On Gizzard Activityuln Layers. J. Apply. Poultry.

Hidayat, C . 2018. Pemanfaatan Insekta Senagai Bahan Pakan Dalam Ransum Ayam Pedaging. Jurnal WARTAZOA. Vol. 28 No. 4 Hal. 161-174.

Ijaiya AT, Eko EO. 2009. Effect Of Replacing Dietary Fish Meal With Silkworm (Anaphe Infracta) Caterpillar Meal On Performance, Carcass Characteristics And Haematological Parameters Of Finishing Broiler Chicken. Pak J Nut. 8:850-855.

Mahardika, I.G. dan Sudiastra, I. W. 2015. Pemanfaatan Dedak Padi Fermentasi Untuk Meningkatkan Pertumbuhan Ternak. Universitas Udayana. Denpasar.

Murtidjo, B. A. 2009. Pedoman Beternak Ayam Broiler. Kanisius. Yogyakarta.

Rasyaf, M. 2006. Penelolaan Peternakan Unggas Pedaging. Kanisius. Yogyakarta.

Ressang, A.A. 1993. Patologi Khusus Veteriner. Edisi-2 Percetakan Bali, Bali.

Resnawati. 2004. Bobot Potongan Karkas dan Lemak Abdominal Ayam Pedaging Yang Diberi Ransum Mengandung Tepung Cacing Tanah. Prosiding. Seminar Nasional
Teknologi Peternakan dan Veteriner. Pusat Penelitian dan Pengembangan Peternakan. Bogor.

Sanchez-Muros MJ, Barroso FG, ManzanoAgugliaro F. 2014. Insect meal as renewable source of food for animal feeding: A review. J Clean Prod. 65:16-27.

Saragih, B. 2000. Agribisnis Berbasis Peternakan. Pustaka Wirausaha Muda. PT.Loji Grafika Griya Sarana, Bogor.

Setiadi, D., N. Khaira dan T. Syahrin. 2011. Perbandingan Bobot Hidup, Karkas dan Lemak Abdominal Ayam Jantan Tipe Medium Dengan Strain Berbeda Yang Diberi Ransum Komersial Broiler. Skripsi. Fakultas Peternakan. Jurusan Peternakan. Universitas Lampung

Siregar, D.M. 2011. Persentase Karkas Dan Pertumbuhan Organ Dalam Ayam Broiler Pada Frekuensi Dan Waktu Pemberian Pakan Yang Berbeda.Skripsi, Departemen Ilmu Produksi dan Teknologi Peternakan. Fakultas Peternakan, Institut Pertanian Bogor.

Soeparno. 1998. Ilmu dan Teknologi Daging. Edisi Ke-3. Gadjah Mada University Press. Yogyakarta.

Subamia, I. W., Nur, B., Musa, A dan Kusumah, R.V. 2010. Manfaat Maggot yang dipelihara dengan Zat Pemicu Warna Sebagai Pakan Untuk Peningkatan Kualitas Warna Ikan Rainbow (Melanotaenia boesmani) asli Papua. Balai Riset Budidaya Ikan Hias Depok. Depok.

Wahyu, J. 1997. Ilmu Nutrisi Unggas. Gadjah Mada University Press. Yogyakarta. 
Winedar, H., Listiyawati dan S. Sutarno. 2006. Digestibility Of Feed Protein, Meet Protein and Increasing Body Weight of Broiler Chicken After
Giving Feed Fermented With Effective Microorganism - 4 (EM4). Journal of Biotechnology 3 (1):14-19 